\title{
Pathogen Inactivation of Human Serum Facilitates its Clinical Use for Islet Cell Culture and Subsequent Transplantation
}

\author{
Magnus U. Ståhle, Daniel Brandhorst, Olle Korsgren, and Folke Knutson \\ Department of Immunology, Genetics and Pathology, Uppsala University, Uppsala, Sweden
}

\begin{abstract}
Serum is regarded as an essential supplement to promote survival and growth of cells during culture. However, the potential risk of transmitting diseases disqualifies the use of serum for clinical cell therapy in most countries. Hence, most clinical cell therapy programs have replaced human serum with human serum albumin, which can result in inferior quality of released cell products. Photochemical treatment of different blood products utilizing Intercept ${ }^{\circledR}$ technology has been shown to inactivate a broad variety of pathogens of RNA and DNA origin. The present study assesses the feasibility of using pathogen-inactivated, blood groupcompatible serum for use in human pancreatic islet culture. Isolated human islets were cultured at $37^{\circ} \mathrm{C}$ for 3-4 days in CMRL 1066 supplemented with 10\% of either pathogen-inactivated or nontreated human serum. Islet quality assessment included glucose-stimulated insulin release (perifusion), ADP/ATP ratio, cytokine expression, and posttransplant function in diabetic nude mice. No differences were found between islets cultured in pathogen-inactivated or control serum regarding stimulated insulin release, intracellular insulin content, and ADP/ATP ratio. Whether media was supplemented with treated or nontreated serum, islet expression of IL-6, IL-8, MCP-1, or tissue factor was not affected. The final diabetes-reversal rate of mice receiving islets cultured in pathogen-inactivated or nontreated serum was $78 \%$ and $87 \%$, respectively (NS). As reported here, pathogen-inactivated human serum does not affect viability or functional integrity of cultured human islets. The implementation of this technology for RNA- and DNA-based pathogen inactivation should enable reintroduction of human serum for clinical cell therapy.
\end{abstract}

Key words: Cell therapy; Cell transplantation; Cell culture; Serum; Pathogen inactivation

\section{INTRODUCTION}

From the very beginning of modern cell culture, serum has been regarded as an essential supplement to provide for survival and growth of cells isolated from different species and tissues (13). Nevertheless, the potential risk of transmitting different diseases disqualified the use of serum for clinical cell therapy in most countries. In spite of the increasing efficiency of pathogen screening protocols, the risk for transfusion-transmitted infections still persists and remains a major concern of public health care (55). Therefore, the majority of clinical cell therapy programs have replaced human serum with human serum albumin.

There are several pathogen inactivation techniques available to treat blood components; however, combined techniques are considered to provide the highest safety for patients (53). The Intercept ${ }^{\circledR}$ technology, routinely applied for pathogen inactivation of platelets and plasma, uses psoralen. Psoralen is comprised of small molecules able to pass through cell membranes and capsids, which subsequently bind to the helical regions of the nucleid acid. When UV-A light of 300-400 nm is emitted, psoralen is cross-linked to DNA and RNA either free or located in the genome, thus blocking both transcription and replication of viruses, bacteria, and protozoa. The efficiency and safety of this technology has been documented for clinical applications of different blood products $(22,35,56)$. Preliminary studies demonstrate the principal suitability of this technology for clinical cell therapy by culturing human $\mathrm{T}$ lymphocytes, mesenchymal stem cells, and isolated pancreatic islets in media supplemented with pathogen-inactivated human serum (54).

The present study was initiated to evaluate the feasibility of pathogen inactivation for culturing isolated human islets of Langerhans. Although adult pancreatic islets are composed of different populations of highly

Received March 31, 2010; final acceptance September 28, 2010. Online prepub fate: November 5, 2010.

Address correspondence to Magnus Ståhle, Department of Immunology, Genetics and Pathology, Uppsala University, Rudbeck Laboratory (C11), Dag Hammarskjölds väg 20, S-75185 Uppsala, Sweden. Tel: +46-70-4250507; Fax: +46-18-507866; E-mail: magnus.stahle@klinimm. uu.se 
differentiated cells that do not grow in vitro, the enormous metabolic demand of this tissue requires careful handling to maintain viability and integrity of these micro-organs in culture. In accordance with the majority of protocols for clinical islet transplantation, isolated human islets were cultured for a period of 3-4 days in CMRL 1066. The culture medium was supplemented with heat-inactivated human serum that was either untreated or pathogen inactivated by means of the Intercept ${ }^{\circledR}$ technology.

\section{MATERIALS AND METHODS}

\section{Pathogen Inactivation}

Whole blood was collected from healthy donors and allowed to coagulate. Collected serum was pathogen inactivated utilizing the Intercept ${ }^{\circledR}$ technology (Cerus Europe BV, Amersfoort, Netherlands) as described for human plasma. Briefly, ABO-matched, freshly collected serum from six different healthy blood donors was mixed and split into two equal portions. While one aliquot was left untreated as control serum, the other portion was treated with the Intercept Processing Set for Plasma. The processing set utilizes a closed system consisting of a series of plastic containers. The serum aliquot $(650 \mathrm{ml})$ was connected via a sterile connection devise and passed through a container of amotosalen hydrochloride $(15 \mathrm{ml}, 6 \mathrm{mM})$ into an illumination container and mixed thoroughly. The mixture was then exposed to 3 joule $/ \mathrm{cm}^{2}$ UVA light $(320-400 \mathrm{~nm})$ from Intercept UVA Illuminator (Cerus). Afterwards, the UVAtreated serum was transferred through a compound adsorption device (CAD) to eliminate amotosalen residues and into a storage container. Both, control serum and pathogen-inactivated serum were then heat inactivated for $30 \mathrm{~min}$ at $56^{\circ} \mathrm{C}$.

\section{Islet Isolation}

Local ethics committees approved all human studies. Research grade pancreata were procured from 12 braindead multiorgan donors within the Nordic Network for Clinical Islet Transplantation utilizing cold perfusion with either University of Wisconsin solution (ViaSpan(C) DuPont Pharmaceuticals Ltd., Herts, UK) or Custadiol (Köhler Chemie GmbH, Alsbach, Germany). All pancreata were processed in a central isolation unit located in Uppsala, Sweden (49).

Islet isolation and purification was performed as previously described utilizing either Liberase HI (Roche, Indianapolis, IN, USA) or collagenase NB1 (Serva, Heidelberg, Germany) for pancreas digestion (16). Subsequent to purification and culture, islet yield and purity were determined in a standardized procedure utilizing a digital analysis system that discriminated dithizone- positive islets and nonstained particles (Cellimage, Uppsala, Sweden) (15).

\section{Islet Culture}

After purification, islets were precultured at $37^{\circ} \mathrm{C}$ in untreated single transfer packs for platelets (Baxter Medical AB, Stockholm, Sweden) (20) utilizing CMRL 1066 (Mediatech Inc., Manassas, VA, USA) supplemented with $10 \mathrm{mM}$ HEPES (Invitrogen AB, Stockholm, Sweden), $10 \mathrm{mM}$ nicotinamide (Swedish Pharmacy, Umeå, Sweden), 2 mM L-glutamine (Invitrogen), $50 \mu \mathrm{g} / \mathrm{ml}$ gentamicin (Invitrogen), $0.25 \mu \mathrm{g} / \mathrm{ml}$ fungizone (Invitrogen), $5 \mathrm{mM}$ sodium pyruvate (Swedish Pharmacy), $20 \mu \mathrm{g} / \mathrm{ml}$ ciprofloxacin (Bayer, Leverkusen, Germany), and $10 \%$ blood group-compatible human serum. After 24-36 h medium was changed and aliquots of 1200 islet equivalents were transferred into untreated petri dishes (Sterilin, VWR, Stockholm, Sweden) and suspended into CMRL 1066 supplemented with 10\% of either control human serum or pathogen-inactivated serum. Subsequent to 3-4 days of culture at $37^{\circ} \mathrm{C}$ islets were harvested and quality assessment was performed.

\section{Islet Characterization}

Stimulated insulin release of 20 equally distributed islets was measured in duplicate during dynamic glucose perifusion (Brandel, London, UK) in order to calculate the stimulation index, which was defined as the ratio between the areas under the curves that were calculated for the low $(1.67 \mathrm{mM})$ and high $(16.7 \mathrm{mM})$ glucose concentrations (20). In some preparations the low glucose values were close to zero, giving a very high stimulation index. Therefore, the maximum stimulation index for any islet preparation has been set to 30 , as this is more physiologically realistic. The insulin content in the effluent, collected in 6-min intervals, was determined by using an enzyme immunoassay specific for human insulin (Mercodia, Uppsala, Sweden). The intracellular insulin content was measured in homogenized islets and normalized to the DNA content determined by means of the Quant-it Picogreen ${ }^{\circledR}$ assay (Invitrogen).

Homogenized islets were also assessed for expression of inflammatory mediators utilizing a Gyrolab? ${ }^{\mathrm{TM}}$ workstation (Gyros AB, Uppsala, Sweden). For each chemokine two monoclonal antibodies had to be loaded into a Gyrolab Bioaffy ${ }^{\circledR} 200$ CD micro-laboratory disk to bind and detect tissue factor (TF, capture: TFE, Enzyme Research Laboratories, South Bend, USA; detection: CD 142, BD Pharmingen, Stockholm, Sweden), monocyte chemoattractant protein-1 (MCP-1, capture and detection: anti-CCL2/MCP-1 R\&D Systems, Minneapolis, MN, USA), interleukin-6 (IL-6, capture: rat anti-human IL-6, BD Pharmingen; detection: anti-human IL-6, R\&D Systems), or interleukin-8 (IL-8, capture and detection: 
anti-CXCL8/IL-8 R\&D Systems). An aliquot of 80 islets was used to measure the ADP/ATP ratio utilizing the ApoGlow kit (Cambrex Bio Science, Nottingham, UK).

Islet in vivo function was assessed in NMRI nude mice (Scanbur AB, Sollentuna, Sweden) rendered diabetic by a single intravenous injection of $90 \mu \mathrm{g} / \mathrm{g}$ alloxan (Sigma-Aldrich AB, Stockholm, Sweden) 3 days prior to transplantation of an aliquot of 3000 islet equivalents beneath the kidney capsule. Blood samples were taken from the recipients' tail vein every 2-4 days and analyzed utilizing a one-touch glucometer (Bayer, Leverkusen, Germany). Pretransplant, the nonfasting serum glucose levels of all recipients exceeded $400 \mathrm{mg} / \mathrm{dl}$. After transplantation nonfasting serum glucose levels $<200 \mathrm{mg} / \mathrm{dl}$ were defined as normoglycemic and considered as graft function. Thirty-five days posttransplant nephrectomy of graft-bearing kidneys was performed to confirm the functional dependency of normoglycemia on the transplanted islets.

\section{Statistical Analysis}

Statistical analysis was performed utilizing Prism 5.0c (GraphPad, La Jolla, CA, USA). Comparison between experimental groups was carried out by the Wilcoxon test for matched samples and Fisher's exact test. Data are presented as medians with range except for dynamic insulin release where data are presented as means \pm SEM. Differences are considered significant at $p<0.05$. Values of $p>0.05$ are termed nonsignificant (NS).

\section{RESULTS}

\section{Islet Characterization}

As shown in Figure 1, the amount of insulin secreted during glucose perifusion was similar in both experimental groups. Also, the incubation in culture medium supplemented with either pathogen-inactivated or control serum did not influence the dynamics of insulin release. The median stimulation index differed only marginally between islets cultured in either pathogeninactivated 11.05 (range 1.2-30) or untreated serum 19.1 (range $1.1-30, \mathrm{NS}, p=0.57$ )

Additionally, no difference was observed regarding the median intracellular insulin content of islets cultured for 3-4 days in pathogen-inactivated 1.45 (range $0.19-$ $10.55 \mathrm{ng} / \mathrm{ng}$ DNA) or control serum 1.45 (range 0.22 7.96 ng/ng DNA, NS) (Fig. 2A).

As depicted in Figure 2B, the median ADP/ATP ratio was slightly higher in islets cultured in pathogen-inactivated serum 0.016 (range 0.01-0.052) when compared to standard culture conditions 0.010 (range $0.01-0.30$ ). However, this difference did not reach statistical significance $(p=0.26)$.

Supplementation with pathogen-inactivated serum did not influence the expression of different chemokines

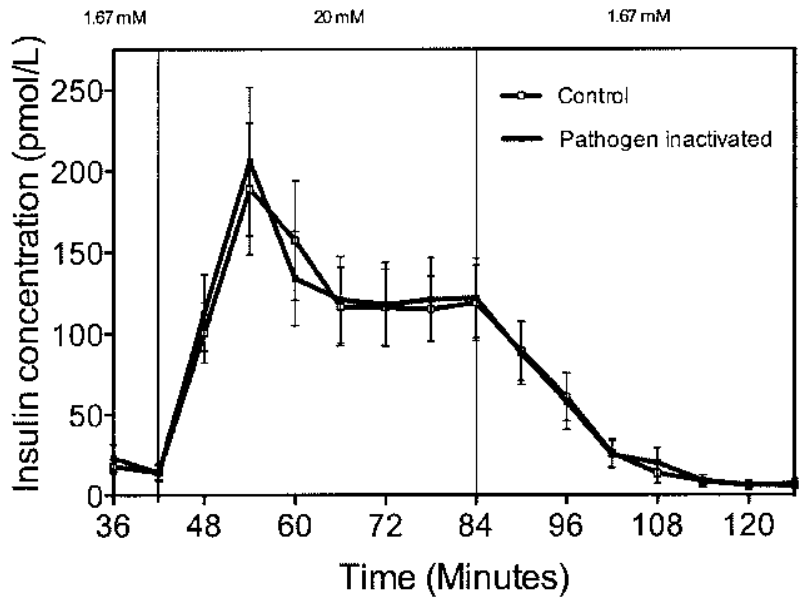

Figure 1. Dynamic insulin release measured during glucose perifusion of isolated human islets cultured for 3-4 days at $37^{\circ} \mathrm{C}$ in CMRL 1066 supplemented with $10 \%$ of either untreated control serum (open squares) or pathogen-inactivated (filled squares) serum. Values are expressed as mean \pm SEM from 12 different islet preparations.

in cultured islets as displayed in Figure $2 \mathrm{C}-\mathrm{F}$. The median expression levels of tissue factor [0.034, range (0.015-0.076) vs. 0.033 (range 0.011-0.052) fmol/?g DNA, NS] (Fig 2C), MCP-1 [0.064 range (0.011-0.82) vs. 0.045 (range 0.010-0.71) fmol/ $\mu \mathrm{g}$ DNA, NS] (Fig. 2D), IL-6 [0.0024 (range 0.0007-0.016) vs. 0.0024 (range 0.0006-0.018) fmol/ $\mu \mathrm{g}$ DNA, NS] (Fig. 2E), and IL-8 [0.058 (range 0.0003-1.210) vs. 0.0023 (range 0.0002-1.090) fmol/ $\mu \mathrm{g}$ DNA, NS] (Fig. 2F) were not affected by the use of pathogen-inactivated serum to that of control serum.

\section{Diabetic Nude Mice Bioassay}

Potency of cultured islets was assessed after transplantation beneath the kidney capsule of diabetic nude mice. In concordance with the findings made for islet in vitro function, reduction of hyperglycemia was similar in islet recipients of either experimental group (Fig. 3). The final cure rate of mice receiving islets cultured in pathogen-inactivated or nontreated serum was $7(78 \%)$ and 8 out of $9(87) \%$, respectively (NS by Fisher's exact test).

\section{DISCUSSION}

Pathogen inactivation with the Intercept ${ }^{\circledR}$ technology was assessed on human serum used for culture of human islets of Langerhans in a clinical setting.

Human islets isolated for clinical purposes are cultured primarily for logistical reasons. Most clinical islet transplant protocols include a culture period of 2-4 days to facilitate pretransplant tissue quality assessment and islet anti-inflammatory pretreatment, recipient matching 
A

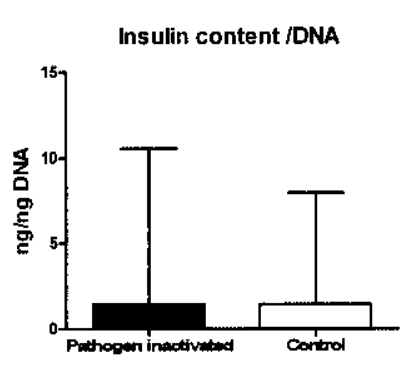

D

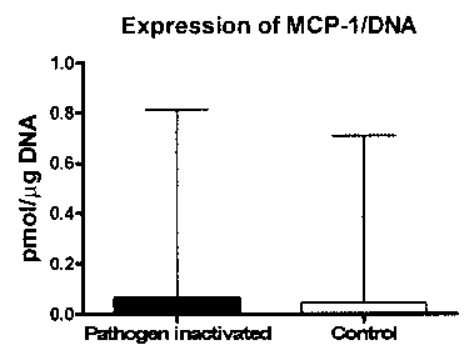

B

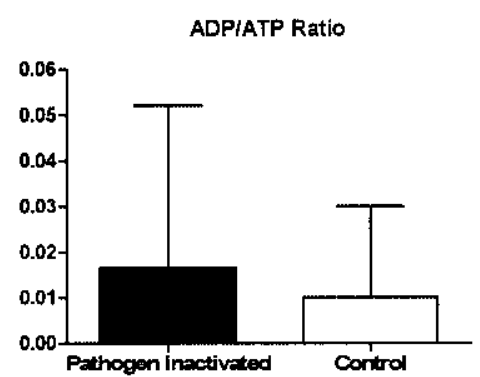

E

Expression of IL-6/DNA

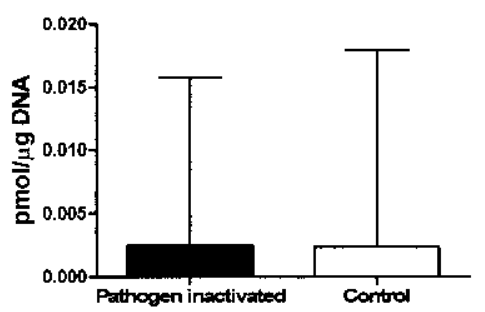

C

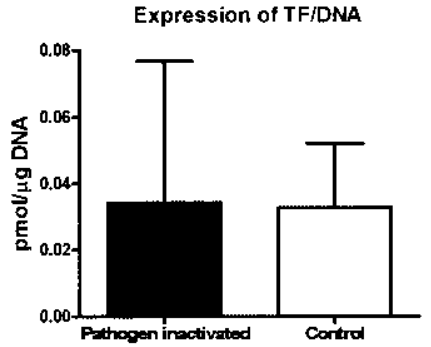

Figure 2. Human islet characterization after $3-4$ days of $37^{\circ} \mathrm{C}$ culture in CMRL 1066 supplemented with $10 \%$ of either untreated control serum (open bars) or pathogen-inactivated serum (filled bars). Characterization included (A) intracellular insulin content, (B) ADP/ATP ratio, and expression of (C) tissue factor (TF), (D) MCP-1, (E) IL-6, and (F) IL-8. Data are expressed as median with range from 12 different islet donors.
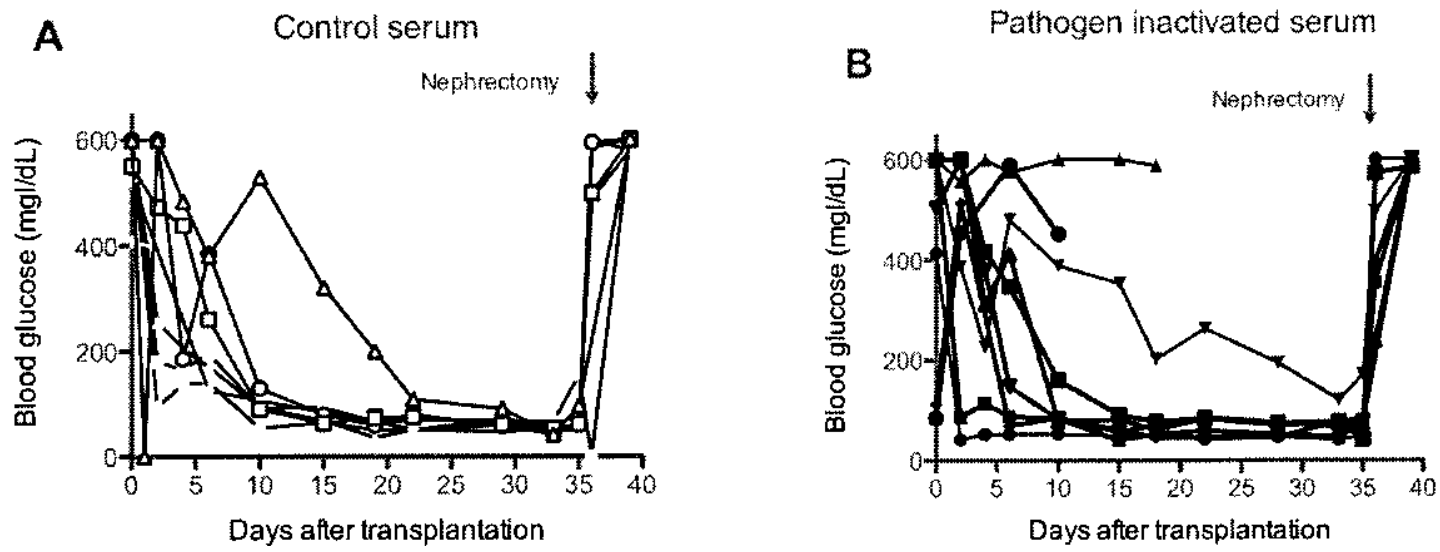

Figure 3. Graft function of cultured human islets transplanted beneath the kidney capsule of alloxan-treated NMRI nude after 3-4 days of $37^{\circ} \mathrm{C}$ culture in CMRL 1066 supplemented with $10 \%$ of either (A) untreated control serum $(n=9$, open symbols) or (B) pathogen-inactivated serum ( $n=9$, filled symbols). Graft removal through nephrectomy (Nx) was performed as indicated at day 35 posttransplant. Presented data are from three different islet donors. 
for transplantation, and induction of immunosuppressive protocols $(6,24,39)$. In addition, different experimental studies indicated that in vitro culture reduces islet immunogenicity compared to freshly isolated islets $(27,29,32)$. A period of culture has benefits not only for islet recovery, as it replenishes islet ATP stores depleted during both cold ischemia period and the isolation procedure, but also increases posttransplant function of human islets transplanted into diabetic nude mice $(2,5,23,26)$.

Supplementation of culture medium with serum seems to be important to preserve the functional and morphological integrity of islets. Serum, if added to a suitable culture medium, prevents fragmentation of cultured islets and preserves the secretory capacity of $\beta$ cells of different species during culture $(1,25)$. This effect seems to be particularly pronounced if serum of the donor species is used for supplementation in comparison to xenogenic serum $(4,18)$.

Although it was previously demonstrated that a minimum percentage of serum is required to preserve functional islet integrity $(1,7)$, a few studies reported that serum-free culture media are superior to serum-supplemented media for function of cultured human islets $(3,14)$. This finding can be related to the observation that human islets are less sensitive toward serum deprivation than islets of other species (40). Nevertheless, serum-free media have to be supplemented with numerous growth factors and nutrients to preserve survival and function of cultured human islets $(17,48)$. Among these additives, serum albumin is considered to be a component that can partially replace serum $(33,38)$. More recent reports clearly emphasize the importance of supplementation of culture media with complete serum compared to human serum albumin because it improves human islet survival, function, and viability $(30,43)$. These observations are in agreement with basic approaches clearly suggesting that the complexity of serum components does not justify the assignment of different growth-promoting abilities to individual protein fractions such as albu$\min (19)$.

Nevertheless, in spite of the obvious advantages to use serum for islet cell culture this essential supplement is in most centers avoided in clinical cell therapy to reduce the risk of transmitting diseases by blood components. The threat to public health concerns particularly the spread of HIV, HCV, HBV, and HTLV. Also, the transmission of bacteria and protozoa still represents significant risks associated with therapeutic utilization of blood components (31).

Although extensive blood donor testing has dramatically reduced the risk of contamination of blood components, transfusion-transmitted infections are still reported. Moreover, the appearance of new pathogens in the population remains a major concern as seen with West Nile virus in North America and the SARS virus in Asia $(12,44)$.

The Intercept ${ }^{\circledR}$ technology using amotosalen and UVA treatment, already in use in many European countries (50), has been reported to be safe in preclinical studies (9-11) and to be well tolerated in a wide range of patients $(22,41,42,45,52,56)$. It has even been used to prevent transfusion transmission of Chikungunya virus during an epidemic (46). The Intercept ${ }^{\circledR}$ technology has proven its efficacy towards bacteria, viruses, and protozoan parasites $(8,21,28,34-37,46,47,51)$. Implementation of this safe and validated method for pathogen inactivation using Intercept ${ }^{\circledR}$ can provide protection from both known and yet unidentified RNA- and DNA-dependent agents.

In conclusion, the present data suggest that human serum treated by Intercept ${ }^{\circledR}$ technology can be used for human islet cell culture without affecting viability and functional integrity. The implementation of this technique for prevention of pathogen transmission would allow for the broad reintroduction of the use of human serum for clinical cell therapy worldwide.

ACKNOWLEDGMENTS: This study was supported by grants from Juvenile Diabetes Foundation International, the National Institutes of Health, Vinnova Sampost, and the Swedish Research Council. The authors would like to thank Anna Karlsson and Elisabeth Wijkström for their excellent work with the Gyros system, Karin Andersson for her skilled work transplanting mice, and Karin Leijskog for providing both control and pathogen-inactivated serum. M.U.S. performed the experiments and participated in islet isolation, data analysis, and writing the paper. D.B. participated in islet isolation, data analysis, and writing the paper. O.K. participated in research design and writing the paper. F.K. participated in research design and writing the paper.

\section{REFERENCES}

1. Andersson, A. Isolated mouse pancreatic islets in culture: Effects of serum and different culture media on the insulin production of the islets. Diabetologia 14(6):397-404; 1978.

2. Andersson, A.; Borglund, E.; Brolin, S. Effects of glucose on the content of ATP and glycogen and the rate of glucose phosphorylation of isolated pancreatic islets maintained in tissue culture. Biochem. Biophys. Res. Commun. 56(4):1045-1051; 1974.

3. Bottino, R.; Inverardi, L.; Valente, U.; Ricordi, C. Serumfree medium and pyruvate improve survival and glucose responsiveness of islet beta cells in culture. Transplant. Proc. 29(4):1978; 1997.

4. Brandhorst, D.; Brandhorst, H.; Hering, B. J.; Bretzel, R. G. Long-term survival, morphology and in vitro function of isolated pig islets under different culture conditions. Transplantation 67(12):1533-1541; 1999.

5. Brandhorst, D.; Brandhorst, H.; Hering, B. J.; Federlin, K.; Bretzel, R. G. The intracellular ATP content of fresh and cultured human islets isolated from different donors. Transplant. Proc. 29(4):1979; 1997.

6. Bretzel, R. G.; Brandhorst, D.; Brandhorst, H.; Eckhard, 
M.; Ernst, W.; Friemann, S.; Rau, W.; Weimar, B.; Rauber, K.; Hering, B. J.; Brendel, M. D. Improved survival of intraportal pancreatic islet cell allografts in patients with type- 1 diabetes mellitus by refined peritransplant management. J. Mol. Med. 77(1):140-143; 1999.

7. Buitrago, A.; Gylfe, E. Significance of serum for the preservation of insulin secretion during culture. Med. Biol. 61(2):133-138; 1983.

8. Castro, E.; Girones, N.; Bueno, J. L.; Carrion, J.; Lin, L.; Fresno, M. The efficacy of photochemical treatment with amotosalen $\mathrm{HCl}$ and ultraviolet A (INTERCEPT) for inactivation of Trypanosoma cruzi in pooled buffy-coat platelets. Transfusion 47(3):434-441; 2007.

9. Ciaravino, V.; Hanover, J.; Lin, L.; Sullivan, T.; Corash, L. Assessment of safety in neonates for transfusion of platelets and plasma prepared with amotosalen photochemical pathogen inactivation treatment by a 1-month intravenous toxicity study in neonatal rats. Transfusion 49(5):985-994; 2009.

10. Ciaravino, V.; McCullough, T.; Cimino, G.; Sullivan, T. Preclinical safety profile of plasma prepared using the INTERCEPT Blood System. Vox Sang. 85(3):171-182; 2003.

11. Ciaravino, V.; McCullough, T.; Dayan, A. D. Pharmacokinetic and toxicology assessment of INTERCEPT (S-59 and UVA treated) platelets. Hum. Exp. Toxicol. 20(10): 533-550; 2001.

12. Drosten, C.; Gunther, S.; Preiser, W.; van der Werf, S.; Brodt, H. R.; Becker, S.; Rabenau, H.; Panning, M.; Kolesnikova, L.; Fouchier, R. A.; Berger, A.; Burguiere, A. M.; Cinatl, J.; Eickmann, M.; Escriou, N.; Grywna, K.; Kramme, S.; Manuguerra, J. C.; Muller, S.; Rickerts, V.; Sturmer, M.; Vieth, S.; Klenk, H. D.; Osterhaus, A. D.; Schmitz, H.; Doerr, H. W. Identification of a novel coronavirus in patients with severe acute respiratory syndrome. N. Engl. J. Med. 348(20):1967-1976; 2003.

13. Eagle, H. Nutrition needs of mammalian cells in tissue culture. Science 122(3168):501-514; 1955.

14. Fraga, D. W.; Sabek, O.; Hathaway, D. K.; Gaber, A. O. A comparison of media supplement methods for the extended culture of human islet tissue. Transplantation 65(8):1060-1066; 1998.

15. Friberg, A.; Brandhorst, H.; Ståhle, M.; Svensson, A.; Korsgren, O.; Brandhorst, D. Digital image analysis of islet samples yields consistent, reproducible results. Xenotransplantation 14(5):389; 2007.

16. Friberg, A. S.; Ståhle, M.; Brandhorst, H.; Korsgren, O.; Brandhorst, D. Human islet separation utilizing a closed automated purification system. Cell Transplant. 17:13051313; 2008.

17. Gaber, A. O.; Fraga, D. W.; Callicutt, C. S.; Gerling, I. C.; Sabek, O. M.; Kotb, M. Y. Improved in vivo pancreatic islet function after prolonged in vitro islet culture. Transplantation 72(11):1730-1736; 2001.

18. Goldman, H.; Colle, E. Human pancreatic islets in culture: Effects of supplementing the medium with homologous and heterologous serum. Science 192(4243):1014-1016; 1976.

19. Gospodarowicz, D.; Moran, J. S. Growth factors in mammalian cell culture. Annu. Rev. Biochem. 45:531-558; 1976.

20. Goto, M.; Eich, T. M.; Felldin, M.; Foss, A.; Kallen, R.; Salmela, K.; Tibell, A.; Tufveson, G.; Fujimori, K.; Engkvist, M.; Korsgren, O. Refinement of the automated method for human islet isolation and presentation of a closed system for in vitro islet culture. Transplantation 78(9):1367-1375; 2004.

21. Grellier, P.; Benach, J.; Labaied, M.; Charneau, S.; Gil, H.; Monsalve, G.; Alfonso, R.; Sawyer, L.; Lin, L.; Steiert, M.; Dupuis, K. Photochemical inactivation with amotosalen and long-wavelength ultraviolet light of Plasmodium and Babesia in platelet and plasma components. Transfusion 48(8):1676-1684; 2008.

22. Hambleton, J.; Wages, D.; Radu-Radulescu, L.; Adams, M.; MacKenzie, M.; Shafer, S.; Lee, M.; Smyers, J.; Wiesehahn, G.; Corash, L. Pharmacokinetic study of FFP photochemically treated with amotosalen (S-59) and UV light compared to FFP in healthy volunteers anticoagulated with warfarin. Transfusion 42(10):1302-1307; 2002.

23. Hellman, B.; Idahl, L. A.; Sehlin, J.; Taljedal, I. B. Influence of anoxia on glucose metabolism in pancreatic islets: Lack of correlation between fructose-1,6-diphosphate and apparent glycolytic flux. Diabetologia 11(6):495-500; 1975.

24. Hering, B. J.; Kandaswamy, R.; Harmon, J. V.; Ansite, J. D.; Clemmings, S. M.; Sakai, T.; Paraskevas, S.; Eckman, P. M.; Sageshima, J.; Nakano, M.; Sawada, T.; Matsumoto, I.; Zhang, H. J.; Sutherland, D. E.; Bluestone, J. A. Transplantation of cultured islets from two-layer preserved pancreases in type 1 diabetes with anti-CD3 antibody. Am. J. Transplant. 4(3):390-401; 2004.

25. Holmes, M. A.; Clayton, H. A.; Chadwick, D. R.; Bell, P. R.; London, N. J.; James, R. F. Functional studies of rat, porcine, and human pancreatic islets cultured in ten commercially available media. Transplantation 60(8): 854-860; 1995.

26. Ihm, S. H.; Matsumoto, I.; Zhang, H. J.; Ansite, J. D.; Hering, B. J. Effect of short-term culture on functional and stress-related parameters in isolated human islets. Transpl. Int. 22(2):207-216; 2009.

27. Jahr, H.; Hussmann, B.; Eckhardt, T.; Bretzel, R. G. Successful single donor islet allotransplantation in the streptozotocin diabetes rat model. Cell Transplant. 11(6):513518; 2002.

28. Jauvin, V.; Alfonso, R. D.; Guillemain, B.; Dupuis, K.; Fleury, H. J. In vitro photochemical inactivation of cellassociated human T-cell leukemia virus type I and II in human platelet concentrates and plasma by use of amotosalen. Transfusion 45(7):1151-1159; 2005.

29. Johansson, U.; Olsson, A.; Gabrielsson, S.; Nilsson, B.; Korsgren, O. Inflammatory mediators expressed in human islets of Langerhans: Implications for islet transplantation. Biochem. Biophys. Res. Commun. 308(3):474-479; 2003.

30. Kerr-Conte, J.; Vandewalle, B.; Moerman, E.; Lukowiak, B.; Gmyr, V.; Arnalsteen, L.; Caiazzo, R.; Sterkers, A.; Hubert, T.; Vantyghem, M. C.; Pattou, F. Upgrading pretransplant human islet culture technology requires human serum combined with media renewal. Transplantation 89(9):1154-1160; 2010.

31. Klein, H. G. How safe is blood, really? Biologicals 38(1): 100-104; 2010.

32. Kuttler, B.; Hartmann, A.; Wanka, H. Long-term culture of islets abrogates cytokine-induced or lymphocyteinduced increase of antigen expression on beta cells. Transplantation 74(4):440-445; 2002.

33. Lee, R. H.; Carter, J.; Szot, G. L.; Posselt, A.; Stock, P. Human albumin preserves islet mass and function better than whole serum during pretransplantation islet culture. Transplant. Proc. 40(2):384-386; 2008.

34. Lin, L. Inactivation of cytomegalovirus in platelet concen- 
trates using Helinx technology. Semin. Hematol. 38(4 Suppl. 11):27-33; 2001.

35. Lin, L.; Cook, D. N.; Wiesehahn, G. P.; Alfonso, R.; Behrman, B.; Cimino, G. D.; Corten, L.; Damonte, P. B.; Dikeman, R.; Dupuis, K.; Fang, Y. M.; Hanson, C. V.; Hearst, J. E.; Lin, C. Y.; Londe, H. F.; Metchette, K.; Nerio, A. T.; Pu, J. T.; Reames, A. A.; Rheinschmidt, M.; Tessman, J.; Isaacs, S. T.; Wollowitz, S.; Corash, L. Photochemical inactivation of viruses and bacteria in platelet concentrates by use of a novel psoralen and long-wavelength ultraviolet light. Transfusion 37(4):423-435; 1997.

36. Lin, L.; Dikeman, R.; Molini, B.; Lukehart, S. A.; Lane, R.; Dupuis, K.; Metzel, P.; Corash, L. Photochemical treatment of platelet concentrates with amotosalen and long-wavelength ultraviolet light inactivates a broad spectrum of pathogenic bacteria. Transfusion 44(10):14961504; 2004.

37. Lin, L.; Hanson, C. V.; Alter, H. J.; Jauvin, V.; Bernard, K. A.; Murthy, K. K.; Metzel, P.; Corash, L. Inactivation of viruses in platelet concentrates by photochemical treatment with amotosalen and long-wavelength ultraviolet light. Transfusion 45(4):580-590; 2005.

38. Ling, Z.; Hannaert, J. C.; Pipeleers, D. Effect of nutrients, hormones and serum on survival of rat islet beta cells in culture. Diabetologia 37(1):15-21; 1994.

39. Moberg, L.; Olsson, A.; Berne, C.; Felldin, M.; Foss, A.; Kallen, R.; Salmela, K.; Tibell, A.; Tufveson, G.; Nilsson, B.; Korsgren, O. Nicotinamide inhibits tissue factor expression in isolated human pancreatic islets: Implications for clinical islet transplantation. Transplantation 76(9): 1285-1288; 2003.

40. Nielsen, J. H. Growth and function of the pancreatic beta cell in vitro: Effects of glucose, hormones and serum factors on mouse, rat and human pancreatic islets in organ culture. Acta Endocrinol. Suppl. 266:1-39; 1985.

41. Osselaer, J. C.; Cazenave, J. P.; Lambermont, M.; Garraud, O.; Hidajat, M.; Barbolla, L.; Tardivel, R.; Defoin, L.; Waller, C.; Mendel, I.; Raidot, J. P.; Kandel, G.; De Meuter, R.; Fabrigli, P.; Dehenau, D.; Arroyo, J. L.; Padron, F.; Gouezec, H.; Corral, M.; Jacquet, M.; Sundin, D.; Lin, L.; Corash, L. An active haemovigilance programme characterizing the safety profile of 7437 platelet transfusions prepared with amotosalen photochemical treatment. Vox Sang. 94(4):315-323; 2008.

42. Osselaer, J. C.; Messe, N.; Hervig, T.; Bueno, J.; Castro, E.; Espinosa, A.; Accorsi, P.; Junge, K.; Jacquet, M.; Flament, J.; Corash, L. A prospective observational cohort safety study of 5106 platelet transfusions with components prepared with photochemical pathogen inactivation treatment. Transfusion 48(6):1061-1071; 2008.

43. Pappas, K. K.; Scott, 3rd, W. E.; Avgoustiniatos, E. S.; Nelson, R. A.; Rozak, P. R.; Ansite, J. D.; Fraga, D. W.; Wildey, G. M.; Boyd, V.; Hering, B. J. Effect of serum on fractional viability of human islets cultured for 2 days (abstract). 8th International Congress of the Cell Transplant Society, Milan, Italy; 2006.

44. Pealer, L. N.; Marfin, A. A.; Petersen, L. R.; Lanciotti, R. S.; Page, P. L.; Stramer, S. L.; Stobierski, M. G.; Signs, K.; Newman, B.; Kapoor, H.; Goodman, J. L.; Chamberland, M. E. Transmission of West Nile virus through blood transfusion in the United States in 2002. N. Engl. J. Med. 349(13):1236-1245; 2003.

45. Pineda, A.; McCullough, J.; Benjamin, R. J.; Cable, R.;
Strauss, R. G.; Burgstaler, E.; Porter, S.; Lin, L.; Metzel, P.; Conlan, M. G. Pathogen inactivation of platelets with a photochemical treatment with amotosalen $\mathrm{HCl}$ and ultraviolet light: Process used in the SPRINT trial. Transfusion 46(4):562-571; 2006.

46. Rasongles, P.; Angelini-Tibert, M. F.; Simon, P.; Currie, C.; Isola, H.; Kientz, D.; Slaedts, M.; Jacquet, M.; Sundin, D.; Lin, L.; Corash, L.; Cazenave, J. P. Transfusion of platelet components prepared with photochemical pathogen inactivation treatment during a Chikungunya virus epidemic in Ile de La Reunion. Transfusion 49(6):10831091; 2009.

47. Roback, J. D.; Conlan, M.; Drew, W. L.; Ljungman, P.; Nichols, W. G.; Preiksaitis, J. K. The role of photochemical treatment with amotosalen and UV-A light in the prevention of transfusion-transmitted cytomegalovirus infections. Transfus. Med. Rev. 20(1):45-56; 2006.

48. Rush, B. T.; Fraga, D. W.; Kotb, M. Y.; Sabek, O. M.; Lo, A.; Gaber, L. W.; Halim, A. B.; Gaber, A. O. Preservation of human pancreatic islet in vivo function after 6 month culture in serum-free media. Transplantation 77(8): 1147-1154; 2004.

49. Rydgard, K. J.; Song, Z.; Foss, A.; Ostraat, O.; Tufveson, G.; Wennberg, L.; Lundgren, T.; Tibell, A.; Groth, C.; Korsgren, O. Procurement of human pancreases for islet isolation - the initiation of a Scandinavian collaborative network. Transplant. Proc. 33(4):2538; 2001.

50. Schlenke, P.; Hervig, T.; Isola, H.; Wiesel, M. L.; Kientz, D.; Pinkoski, L.; Singh, Y.; Lin, L.; Corash, L.; Cazenave, J. P. Photochemical treatment of plasma with amotosalen and UVA light: Process validation in three European blood centers. Transfusion 48(4):697-705; 2008.

51. Singh, Y.; Sawyer, L. S.; Pinkoski, L. S.; Dupuis, K. W.; Hsu, J. C.; Lin, L.; Corash, L. Photochemical treatment of plasma with amotosalen and long-wavelength ultraviolet light inactivates pathogens while retaining coagulation function. Transfusion 46(7):1168-1177; 2006.

52. Snyder, E.; McCullough, J.; Slichter, S. J.; Strauss, R. G.; Lopez-Plaza, I.; Lin, J. S.; Corash, L.; Conlan, M. G. Clinical safety of platelets photochemically treated with amotosalen $\mathrm{HCl}$ and ultraviolet A light for pathogen inactivation: The SPRINT trial. Transfusion 45(12):1864-1875; 2005.

53. Solheim, B. G.; Seghatchian, J. The six questions of pathogen reduction technology: An overview of current opinions. Transfus. Apher. Sci. 39(1):51-57; 2008.

54. Ståhle, M.; Carlsson, B.; Le Blanc, K.; Korsgren, O.; Knutson, F. Photochemical pathogen inactivation of human serum enables its large-scale application in clinical cell transplantation. Vox Sang. 98:e364-e365; 2010.

55. Vamvakas, E. C.; Blajchman, M. A. Transfusion-related mortality: The ongoing risks of allogeneic blood transfusion and the available strategies for their prevention. Blood 113(15):3406-3417; 2009.

56. van Rhenen, D.; Gulliksson, H.; Cazenave, J. P.; Pamphilon, D.; Ljungman, P.; Kluter, H.; Vermeij, H.; KappersKlunne, M.; de Greef, G.; Laforet, M.; Lioure, B.; Davis, K.; Marblie, S.; Mayaudon, V.; Flament, J.; Conlan, M.; Lin, L.; Metzel, P.; Buchholz, D.; Corash, L. Transfusion of pooled buffy coat platelet components prepared with photochemical pathogen inactivation treatment: The euroSPRITE trial. Blood 101(6):2426-2433; 2003. 
